\title{
THE CAUSE OF UNHAPPINESS IN QOHELET 3:11
}

\author{
Aron Pinker \\ Silver Spring, Maryland, USA
}

\begin{abstract}

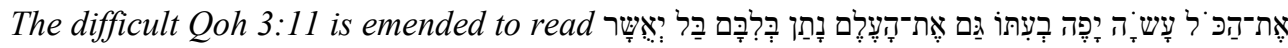

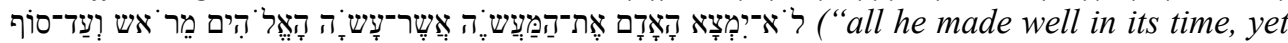
he placed the unknowable in their heart, not to make him happy, man cannot find out the work which God made from beginning to end"). It is argued that 3:11 a is better understood as referring to the creation of the world, rather than to the catalogue of times in 3:2-8, and

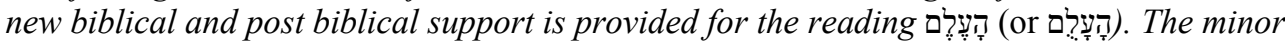

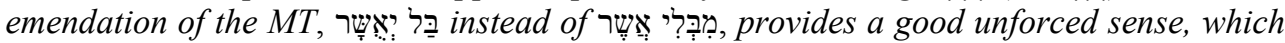
is in line with ancient wisdom thinking.
\end{abstract}

Keywords: Qohelet, Happiness, Biblical Scholarship, Wisdom Literature

\section{Introduction}

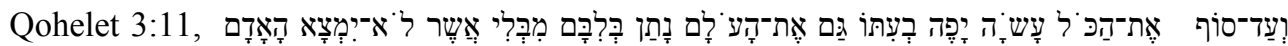

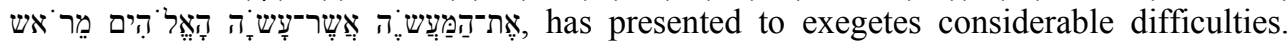
Crenshaw notes that Qoh 3:11 "has been a Walpurgisnachts-Traum [nightmarish dream] for all commentators. This nightmare of interpretation does not derive simply from the presence of the much-discussed ha olam, but from the total sentiment of the verse." Similarly, Longman says: "This verse is widely thought to be one of the hardest in the book to interpret, but its difficulty is not a function of the vocabulary. Taken individually, the words are fairly common; the question centers on their precise meaning in the present context."

The verse begins with a positive assessment about all that God has made; all was made well and at the right time. Thus, the גם wת־העלם would imply that placing את־העלם in "their hearts" was a positive heavenly act. However, whichever meaning commentators adopted for העלם the second hemistich appears to be a frustrating negative assessment of man's lot. The first hemistich, sandwiched between two essentially negative observations (3:10 and $3: 11 \mathrm{~b})$ seems out of context. Was it in the Urtext?

We also encounter in Qoh 3:11 an unusual double negation מבלי אשר לא, which is regularly justified by the occurrence of the idiom המבלי אין in Ex 14:11, 1 Kgs 1:3, 6, and 16 and assumed to convey a strengthened negative. However, the cases are not grammatically the same, making מבלי אשר לא in Qoh 3:11 unique. Is this form original?

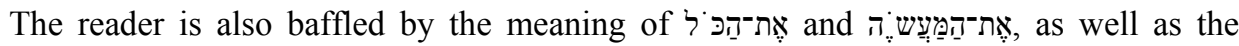

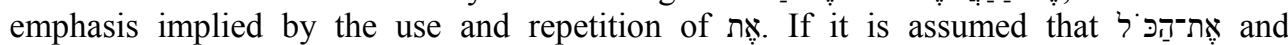

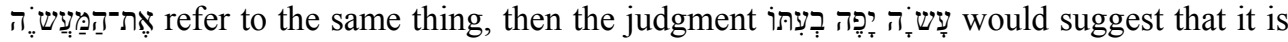

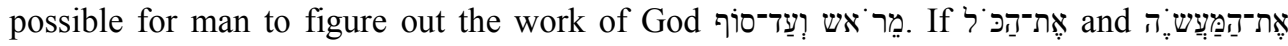
refer to God's different acts, what are they and in what do they differ?

Crenshaw, JL. "The Eternal Gospel (Eccl. 3:11).” In Essays in Old Testament Ethics (eds. Crenshaw, JL and Willis, JT). New York: KTAV (1974:28).

2 Longman, T. The Book of Ecclesiastes. NICOT. Grand Rapids: Eerdmans (1998:118). 
Kaiser says that 3:11 talks of "a deep seated desire, a compulsive drive ... to know the character, composition, and meaning of the world ... and to discern its purpose and destiny." While these human sentiments persist to this day and cannot be denied to

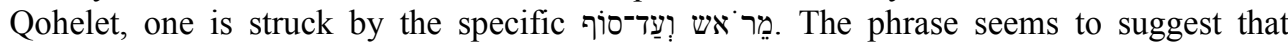
Qohelet had in mind something more detailed and technical. Perhaps, he hoped for the availability of a deterministic process that can be followed and would lead to an unequivocal conclusion, not just the ability to observe the end result and speculate about its causes. What might have been the process that Qohelet had in mind?

In the following we would deal with these questions. In particular, we would argue that in 3:11 Qohelet expresses the frustration of the wise man, stemming from his inability to find an orderly, logically consistent understanding of reality, using the knowledge base of חכמה

\section{Discussion}

The unit Qoh 3:10-15

The unit begins with the keyword ראית, which typically in the Book of Qohelet indicates the beginning of a new theme. ${ }^{4}$ Its end is v.15, since v. 16 begins with ראיתי ועוד, thus starting a new theme. The unit's theme can be sensed from the occurrence of the words

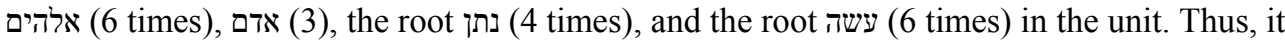
deals with God's and man's deeds, and more specifically with "The relation between God and man."

Fox titles this unit "The Implications of this Principle," where the principle referred to is: there is an appropriate time for every act (vv. $3: 1-9){ }^{5}$ Several other commentators (Rashbam, Ibn Ezra, Galling, Blenkinsopp, Ginsberg, etc.) also viewed 3:11 as related to 3:1-8. However, the list in Qoh 3:2-8 speaks about timeliness, but leaves unanswered the question of whether timeliness is good or not. If 3:11a would have immediately followed 3:1-8 we might have considered it as giving a very positive perspective on those first eight verses. That, however, is not the case.

Attempts to create a linkage between 3:1-8 and 3:11a rest on a single word (בעתו), reach out to an observation that has been concluded in the rhetorical question of v. 9, and lead to artificial interpretative notions. On the other hand, repetition of אלהים ,אשר, האדם, , אתן, and of ראיתי strongly link 3:11 to 3:10 textually and thematically. The marker clearly identifies the beginning of the two verse unit $3: 10-11$. $^{6}$ Moreover, because of challenges in understanding v. 11 as well as vv. 14-15, it seems more prudent to view the unit 3:10-15 as an independent unit dealing with the general topic of God-man relationship, and within this unit to consider 10-11 as a sub-unit.

\footnotetext{
Kaiser, WC (jr.) Ecclesiastes: Total Life. Everyman's Bible Commentary. Chicago: Moody (1979) 66.

Kroeber, R. Der Prediger. Berlin: Akademie-Verlag (1963) 30-42. Kroeber calls attention to the sectional

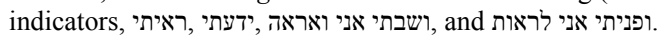

5 Fox, MV. A Time to Tear Down and a Time to Build Up: A Rereading of Ecclesiastes. Grand Rapids: Eerdmans (1999:209).

6 Kroeber, Prediger, 30-42.

7 Pinker, A. “Qohelet 3:14-5.” BZ 54,2 (2010:253-271).
} 


\section{Interpretation of Qoh 3:11}

In the sub-unit consisting of vv. 10-11 the most challenging verse to interpret is v. 11 and the most problematic phrase in it is את־העלם. It is not clear how the Septuagint understood את־העלם It renders "the whole world" ( $\sigma \mu \pi \alpha v \tau \alpha \tau \nu \alpha v \alpha)$. Barton notes that versions B, C, and $\mathrm{V}$ of the Septuagint indicate that an early reading might have been ואת כל עלם Peshitta understands עלם as "the world." It is not clear, however, whether "he made dear to man's heart" for נתן בלבם, represents a different Vorlage or it is interpretative. The Targumist injects a lengthy historical incident into his translation. Only Qoh 3:11a can be identified in the Targum. Still it is possible to extract from the translation that in the

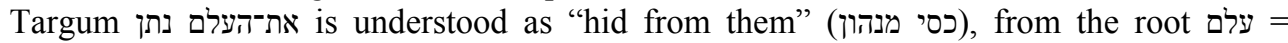
"hide," and refers to the "the ineffable Name of God" (שמא רבא) (כסון) and day of death. The

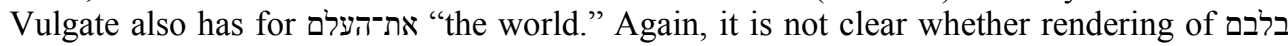
as "he [God] has handed over the world to their contention" is interpretative or

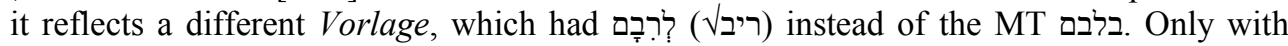
respect to "the whole world" or "the world" is there a tenuous majority among the Versions, depending on how the Septuagint understood the phrase. These observations indicate that already the Versions struggled with this difficult verse, but it is not clear whether they used different copies of the text.

את־העלם Classical Jewish exegetes (Rashi, Ibn Ezra, Rashbam) also differ on how should be understood and the verse interpreted. Rashi (1040-1105) tries to incorporate two meanings of העלם, "wisdom of the world" (חכמת העולם) and "concealed" (העלמה). "However,

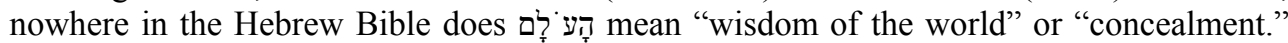
Rashbam (c. 1085-1174) tries to adhere to the literal meaning of הָע "לָּם "eternity," taking it as composed of different seasons, of prosperity and adversity, exemplified in verses $2-8 .{ }^{10}$ This is a strange interpretation, extremely forced and artificial. Man does not need to understand that "there are good seasons and bad seasons." He directly observes that Ibn Ezra (1089- c. 1164) interprets the phrase בלבם גם את העלם נתן saying: "people are engaged as if they would live forever." Because of this engagement they cannot understand the work of God from the beginning to the end. However, it is not obvious that there is a cause and effect relationship between "living forever" and "understanding the work of God from the beginning to the end." 11 Did Ibn Ezra believe that a full understanding of God's work is possible? Perhaps some doubt on his part can be detected in his comment: "There are those that understand העולם the way the sages used it, the sense being as in "פאות העולם "desires of the world, worldly temptations")." Indeed, the meaning "world" for עולם העכולם is mostly Mishnaic, though it does occur in this sense in Sir 3:18: מעט נפשך מכל גדולות עולם. However,

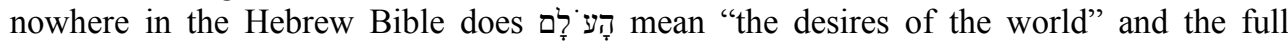
biblical phrase from which תאות העולם (Gen 49:26).

Modern scholarship has not come up with better and more satisfying insights into Qoh $3: 11$. As we shall see from some illustrative examples, commentators tried unsuccessfully to link v. 3:11 with the catalogue of times in 3:1-8. For instance, Galling takes 3:11a as an allusion to a favourable moment for action that brings it to the desired conclusion. ${ }^{12}$

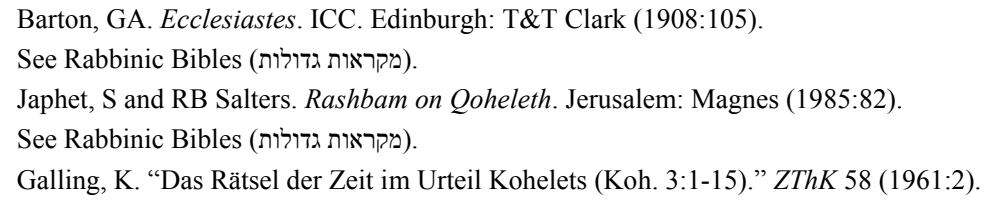


However, in that case 3:11b would present an abrupt thematic shift, since it does not speak of seasons and timeliness, but rather of an original heavenly designed human deficiency. Yet, the presence of גaggests that 3:11 should be considered a single theme. Moreover, if 3:11a thematically belongs to $3: 1-8$, it would be a concluding statement, making superfluous, and 3:11b a hanging statement.

Blenkinsopp also views 3:11a as related to 3:1-8. He apparently understands the expression יפה בעתו in the sense "appropriate to its time": that is, while God makes everything happen, the proper fulfillment of the activities listed in 3:2-8 (and presumably the success of the overall divine plan for the world) are dependent solely on humanity's ability to determine these times and to act in accordance with them. ${ }^{13}$ One would have then expected a statement to the effect that wisdom provides such capability. However, the double negation preceding the last colon makes it patently clear that no man can fully understand God's work.

Ginsburg felt that 3:11 is linked to the preceding 3:10, and 3:11a should be understood in this context. However, the lingering influence of 3:1-8 led him to the meaningless interpretation: "On examining the employments which God has assigned to man, Qoheleth found that the benign Creator has made them beautiful in their respective seasons." $" 14$

Some commentators sensed that Qohelet is alluding in 3:11 to the creation in the first chapter of Genesis, For instance, Jastrow considers 3:11a unlinked to 3:1-8. He takes it as an extraneous comment mitigating the negative tenor of 3:9-10. Because of Qohelet's negative tenor: "The pious commentator interposes a counter-reflection (iii. 11a), 'He has made everything beautiful in its season,' with an allusion perhaps to the refrain in the first chapter of Genesis." ${ }^{15}$ With respect to the assumed pious commentator's interspersion we may ask: "Of what relevance to 3:9-10 is his emphasis on 'in its season'?" and "Why didn't he place his comment after verse $3: 11$ ?"

The possibility that 3:11a might allude to the first chapter of Genesis has been noticed also by others. Wildeboer says: "Koh hat nichts einzuwenden gegen das wiederholte Zeugnis des Schöpfungsberichts in Gen 1." Similarly, Plumptre felt that here "The thinker rests for a time in the primeval faith of Israel that all things were created 'very good' (Gen. i. 31)." More recently, Longman observed that: "the subtle allusions to creation by the use of carefully chosen vocabulary take us back to the beginning of time, though it does not exclude what God has done since that time."18 The root עשה, which is used three times in 3:11, may mark the reference to a עשה - עשה - version of the creation story. ${ }^{19}$ The word טוב in Gen 1:4,10,12,18,21, and 31. ${ }^{20}$ This word seems to parallel טובה in Qoh 5:17.

13 Blenkinsopp, J. “Ecclesiates 3.1-15: Another interpretation.” JSOT 66 (1995:61-62).

14 Ginsburg, CD. Cohelet, Commonly Called the Book of Ecclesiastes. London: Longman (1861:308).

15 Jastrow, MA. Gentle Cynic, Being a Translation of the Book of Koheleth, Commonly Known as Ecclesiastes, Stripped of Later Additions, also its Origin, Growth, and Interpretation. Philadelphia: Lippincott (1919:210) and note 43 .

16 Wildeboer, DG. Der Prediger. KHKAT XVII: Die fünf Megillot. Tübingen: Mohr (1898:133).

17 Plumptre, EH. Ecclesiastes; or The Preacher, with notes and introduction. Cambridge: Univ. Press (1988:131)

18 Longman, Ecclesiastes, 119.

19 Pinker, A. "Ben Zoma's Query on Genesis 1:7: Was it what drove him insane?" Journal of Judaism 55, 3-4 (2006) 51-58. Pinker suggests that Ben Zoma's upheaval (שיערה) in Genesis Rabba 4:7 was a consequence of his realization that Gen 1:7 is a conflated text of a עמר - עשה - version with.

20 Why didn't Qohelet use טוב? In BH יפה " usually means "fair, beautiful," but in Mishnaic Hebrew it often signifies "good." Qohelet 5:17 indicates that this usage of יפה יפוב? in the sense "good" may have started already 
Also, Ben Sira uses טוב instead of יפה when he apparently paraphrases 3:11a. ${ }^{22}$ Fox's view that in Qoh 3:11a "Koheleth is not focusing on God's initial actions during the seven days of Creation so much as on the quality of the results, the way things are now," is entirely interpretative. $^{23}$ Schoors, too, does not believe that 3:11 alludes to the Creation story in הכל 3enesis. He notes that: "Twice is הכל 3:11 the subject of God's making (3:11, 11:5). In does not refer to the universe but to all that happens in human life, as the merismic pairs in vss. 2-8 show." In his view "the frequent use of הכל in Qohelet signifies that in general his sayings are philosophical and concern the totality of all that happens under the sun, i.e., in human life in this sub-lunar world." 24 Similarly, with respect to עשה, Schoors emphasizes that "in most cases עשה in connection with God does not refer to his work as Creator but to his actual interference in the life of human beings, the exception being the remark in 7:29." ${ }^{25}$ However, the at the beginning of 3:11b militates against such an understanding. Whatever meaning העלם is assumed to have, it makes sense to accept that any human characteristic was introduced by God into man at creation. This position is bolstered by the vocabulary used in 3:11 טוב/יפה ,עשה ,כל [Gen 41:2, 5], האדם ) and the concept of timeliness (בעתו), so reminiscent of Genesis 1. Thus, in 3:11a Qohelet must refer to "all, the universe," which has been created in the first six days.

It seems that some commentators may have been impressed by the proximity of the list of seasons in 3:2-8 and the occurrence of בעתו in 3:11a. According to the accents connected with בעתו, but the list of opposites in 3:2-8 only stresses one aspect - timeliness, and does not even allude to any positive value of the mentioned events. We cannot assume that an event יפה יפה , יפה is automatically because then be superfluous in 3:11a. The link between $3: 11 \mathrm{a}$ and Genesis 1 appears to be much stronger than that with $3: 1-8$, both thematically and textually.

The crux הָע לָָ has been rendered: (1) "eternity"; (2) "concealment," and thus "ignorance"; (3) "knowledge"; (4) "world"; (5) "future"; and, (6) "toil," from obtained

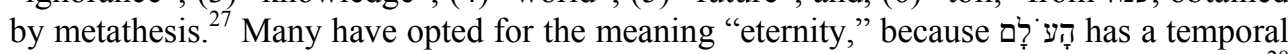
sense in the Hebrew Bible, and Qohelet uses it in this sense $(1: 4,10,2: 16,3: 14,9: 6){ }^{28}$

when the Book of Qohelet was written. It is possible to speculate that he preferred an equivalent of מופה that was just becoming popular. Also, Qohelet uses twice in the following verse, where it functions substantively rather than adjectivally, in the sense of "pleasure, happiness." Using in 3:11 might have implied the wrong idea.

21 Isaksson, B. Studies in the Language of Qoheleth. Studia Semitica Uppsaliensa 10. Uppsala: Uppsala University Press (1987:79).

22 Ben Sira 39:16 reads מעשי אל כלם טובים וכל צורך בעתו יספיק and so almost does 39:33 (where לכל occurs instead of וכל וכיה in 14:16, 24:18, 25:21, 26:16-17, etc.

23 Fox, MV. Ecclesiastes קהלת. Philadelphia: JPS (2004:23).

24 Schoors, A. The Preacher Sought to Find Pleasing Words: A Study in the Language of Qoheleth. Volume II: Vocabulary. OLA 143. Leuven: Peeters $(2004: 4,9)$.

25 Schoors, Preacher II:79-80.

26 Genung, JF. Words of Koheleth: Son of David, King of Jerusalem. Boston: Houghton \& Mifflin (1904) 246. Genung says: "The timeliness of a thing is its beauty; without its occasion as a complementing element, it is only the divided half of a fitting result, and so inert or abnormal." This would imply that and and and and a the same but also different.

27 Gordis, Koheleth - The Man and his world, 231. We added to Gordis' list "future" and "toil."

28 Seow, CL. Ecclesiastes: A New Translation with Introduction and Commentary. Anchor Bible 18C. New Haven: Yale Univ. Press (1997) 163. Seow rationalizes: "In the end, it appears that hā'ôlām in 3:11 must mean the same thing as 'ôläm only three verses later (v 14) and elsewhere in the book $(1: 4,10 ; 2: 16 ; 9: 6$; 12:5). It is difficult to imagine that the ancient reader would not associate 'ôlām in v. 11 with lé 'ôlām only three verses later, in v 14." However, it is not unusual in the Hebrew Bible for the same word in two different 


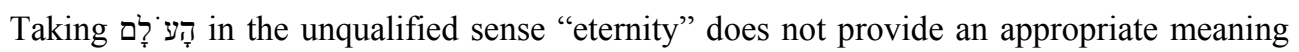
for the verse. Barton is right in his criticism that: "To say that 'God has put eternity in their heart, so that they cannot find out the work of God from beginning to end,' makes no sense." 29 According to the biblical account, man was expelled from the Garden of Eden to avoid such a possibility.

Already Ginsburg felt that "eternity" by itself is unsatisfactory. He interpretatively expanded it, explaining: "he has also implanted in the hearts of men a desire for that which is beyond time." ${ }^{30}$ Similarly, Plumptre understood placing העלם in man's heart as having: "also the sense of a purpose working through the ages from everlasting to everlasting, but 'beginning' and 'end' are alike hidden from him and he fails to grasp it." ${ }^{, 31}$ It is very doubtful that Qohelet could have expected a reader of his book, or a listener to his lectures,

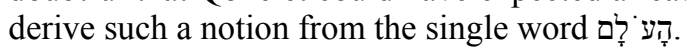

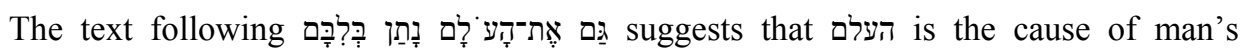
inability to fully understand the 'works of God,' it prevents man's full comprehension. This would imply that העלם might connote "concealment," as has been mentioned by Rashi. Indeed, such a sense for העלם had attained acceptance in the past and has gained followers in recent years. ${ }^{32}$ Barton notes that "Döderlein, more than a century ago, pointed toward the right interpretation when he rendered it 'hidden,' or 'unknown.' Graetz saw that it meant 'ignorance,' while Plumptre hesitatingly, and Haupt more positively, have followed this lead. The root עלם means 'hidden,' 'unknown,' על עלם 'ע, the unknown of time, hence 'of old,' 'forever,' 'eternity.' From this same root עלם 'עלם, frequently used in the Talmud, means 'that which is concealed,' 'secret,' etc. The context in our verse compels us to render it 'igno-

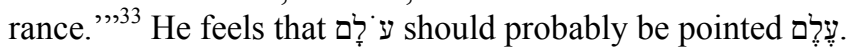

While in the Hebrew Bible דָ דָ has almost always a temporal sense there is no reason why in an unpointed text it might not have another meaning here. ${ }^{34}$ In 14 cases with the article, only one (1 Chr 16:36) besides that before us, omits the 1. However, the text in 1

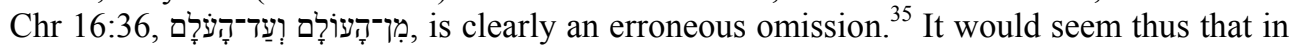
our case the 1 was omitted because it had a different meaning. Indeed, it can be argued that the Massorates have not understood this verse, and being in doubt they followed the

senses to occur in the same verse. A list of such words can be found in GR Driver, "Problems and Solutions," VT 4 (1954) 242. Moreover, as Lohfink noted: "Die übliche Auslegung Kohelets ist statisch. Man setzt immer schon das gesamte Buch als bekannt voraus und interpretiert von diesem 'Kontext' her die Einzelaussage.

Doch die Frage ist, ob nicht gerade in diesem philosophischen Buch viel starker die prozessuale Leserführung beachtet werden müßte. Und das sogar in seiner Lyrik. Das Buch will nicht eine festliegende Botschaft hinüberbringen, sondem im Leser etwas in Gang setzen. Es käme also auf eine Satz-um-Satz-Lektüre, auf eine leseprozeßorientierte Interpretation an, in der das, was hinter einer gerade erreichten Textstelle folgen wird, für deren momentane Auslegung noch nicht berücksichtigt werden darf. Natürlich ist dann an späteren Stellen, die den Leser zu Revisionen seiner ersten Reaktionen zwingen, auf die früheren Stellen zurückzukommen." Cf. Lohfink, N. "Freu dich, Jüngling - doch nicht, weil du jung bist : zum Formproblem im Schlussgedicht Kohelets (Koh 11,9-12,8).” Biblical Interpretation 3,2 (1995:161).

29 Barton, Ecclesiastes, 105.

30 Ginsburg, Cohelet, 308.

31 Plumptre, Ecclesiastes, 132.

32 Whitley, CE. Koheleth: His Language and Thought. BZAW 148. Berlin/New York: de Gruyter (1979) 52-53; and Whybray, RN. Ecclesiastes: based on the Revised Standard version. NCB. Grand Rapids, Mich.: Eerdmans (c1989:73-74).

33 Barton, Ecclesiastes, 105.

34 Jenni, E. “Das Wort ‘ôlām im Alten Testament, III.” ZAW 65 (1953:1-35).

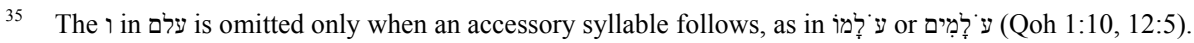




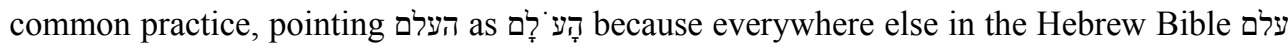
with the article is הָע דָׁם

The noun עֶֶֶם ("secret, forgetfulness") does not occur in the Hebrew Bible or Talmud. Still there are indications that עִּלֶם ("lad") might have connoted also "hidden," "unknown," or "ignorant of." In bYebamot 76b we find התם קרי ליה נער והכא קרי ליה עלם "עפ" "there he calls

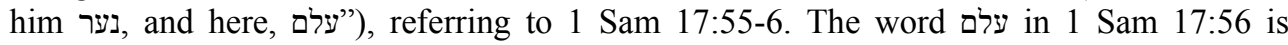
explained by Abner's inability to state the law regarding David's personal status, ממלם ("the law became hidden from you [Abner]"), implying that עלכה נתעלמה (עלו could be understood as "hidden." Also in bAbodah Zara 35b we read עלוּמות קרי ביה (read it secret things"), a play on עִ עִלָמוֹת in Cant 1:3. Ben-Reuven has shown that in two cases in the

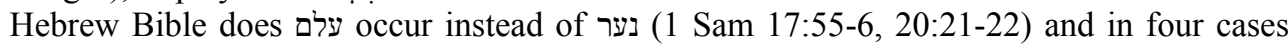
does עלמה occur instead of עלמה 24:43-44, Isa 7:11, 14, Ex 2:8, Prov 30:18-20), and all these cases deal with the unknown or intentionally concealed. ${ }^{36}$ Seemingly עלמה עלם (על were chosen because they connoted "concealment" or "lack of knowledge." Additional support for the meaning "concealment, ignorance" can be drawn from the Ugaritic stem glm, "to be dark." ה' ונעלם מאדם פעלו

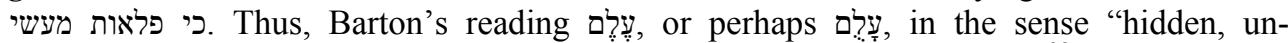
knowable," seems justified, though neither is attested in the Hebrew Bible. ${ }^{38}$

Some commentators emend עִ עִלֶם the and derive its meaning, "intelligence, or the active faculty of knowing," from the Arabic 'aloma, "wisdom, knowledge." Support for this meaning can, perhaps, be found in the observation that "in the Old Testament, something God has put into someone's heart is something this person can do or knows." ${ }^{39}$ Still, the emendation is arbitrary and unwarranted, and the support for this meaning of העלם is rather meager. No such word can be found in Akkadian, Aramaic, or Rabbinic Hebrew. We would have expected Qohelet to use החכמה (Ex 36:2) in a book focused on wisdom rather than an obscure term for "knowledge," and read in the following text what this capability entails, not its shortcomings. Furthermore, to what kind of knowledge does Qohelet refer? It would seem from what follows in the verse that the 'knowledge' given to man is that he does not know. In this case we may as well say that "he placed the unknowable in their hearts," which is adequately captured by עֶלֶ.

Modern scholars suggested for הָע "רָם "Weltsinn" (worldly-mindedness, world-sense), "grasp of the world," or "love of the world." However, support for the meanings "knowledge, worldly knowledge, grasp of the world" is rather meager, or non-existent. These understandings are precluded by the evident antithesis between עשה יפה and עלם Furthermore, the particle גם, which has here an adversative force, yet, but, though, as in Qoh 4:8,16, 5:18, and 3:13, shows that it is connecting two ideas that express (or imply) a contradiction,. Moreover, were it the case that means "knowledge, worldly knowledge, love of the world, grasp of the world," we would have expected to read in the following text what this capability entails, not its shortcomings. Finally, having "knowledge, worldly knowledge, love of the world, grasp of the world" does not imply

36 Ben-Reuven, S. “עלם ועלמה במקרא." Beth Mikra 95,4 (1983:320-321).

37 Dahood, M. “Canaanite-Phoenician Influence in Qoheleth.” Bib 33 (1952:206). The Ugaritic consonants g. and ' are both equivalent to Hebrew ע.

38 Graetz, H. Kohelet קהלת oder der Salomonische Prediger. Leipzig: Wintersche Verlag (1870:192-193). He says: "vielleicht עֶֶַׁ Unwissenheit, Unkunde. Nur diesen Sinn kann der schwierege Vs. III, 11 haben."

39 Schellenberg, A. Erkenntnis als Problem. Qohelet und die alttestamentliche Diskussion um das menschliche Erkennen. Orbis Biblicus et Orientalis 188. Freiburg: Vandenhoeck \& Ruprecht (2002:129).

40 Stuart, M. Commentary on Ecclesiastes. New York: Putnam (1851:149). 
knowledge of the ways of God, nor should it hinder such an understanding. Thus the following emphatic negation of this capability is unwarranted. Plumptre was right saying that: "All interpretations resting on later ideas of the 'world,' as meaning simply the material universe, or worldly pleasures, or worldly wisdom, have to be rejected as inconsistent with lexical usage."

The emendation of עלם into על המל assuming metathesis has been noted in BHK and adopted by some. Tur-Sinai says: "In the Hebrew Bible העולם is an adverb not a noun, as in the Talmudic literature. However, if we look for parallels in the Book of Qohelet, as in particular in 8:17...then we shall recognize that the simple meaning is in metathesis: העמל מהמל

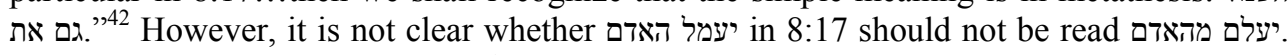
Moreover, as Ps 107:12 indicates, עמל is extraneous to the heart, the seat of knowledge and emotion.

The double negation מבלי אשר לא has been in the past translated by "so that not," "that not," "without that," "only that not." However, none of these translations can be anchored in the MT. Graetz thought that מבלי is a dittographic error of בלבי אשר לא Currently is routinely interpreted as a strengthened negation. For instance, Gordis says: "מבלי אשר לארי לאי לאר is a pleonasm. The double negatives strengthen the negative; cf. Ex. 14:11, המבלי אין קברים (Barton)." ${ }^{.44}$

The simple emendation of בלבם בל יאשר into requires only the assumption

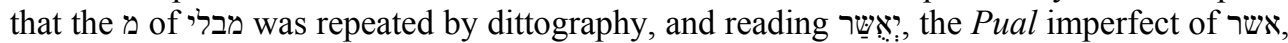
meaning "go straight, go on, advance." The form : (Qere) occurs in Ps 41:3, where it probably has the secondary meaning "be happy," because of doing the right thing; i.e., going straight. Thus, גם את העלם נתן בלבם בל יאשר could be understood as meaning "he also placed the unknowable in their heart, so that (man) would not be happy (by being able to go straight)." In Sir 4:17 we read that wisdom would lead man on the right path and reveal to him its secrets (וגליתי לו מסתרי אאשרנו), Qohelet in 3:11 asserts that some parts of knowledge will forever remain unknown, denying man the right path and accompanying satisfaction.

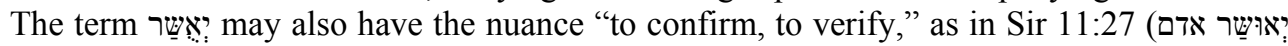
בטרם תחקור אדם אל תאשרהו כי באחריתו asserts that the 'unknowable' placed in man's heart does not allow certainty of deduction, no conclusion would be necessarily confirmed.

The reading גם את העלם נתן בלבם בל יאשר would be in line with the quest of ancient wisdom, as noted by Schmid: "In essence the goal of wisdom instruction was the recognition of the right time, the right place and the right degree of human conduct." Just as we read in The Instruction of Ani that "Man does not have a single way, the lord of life confounds him," so Qohelet, too, felt frustrated by wisdom's inability to accord certitude of insight. A wise man cannot be happy knowing that the wisdom did not enable him to understand God's work from beginning to end. ${ }^{46}$

The phrase "מֵר אש וְעַד־סוֹף "from the beginning and to end," is a unique in the Hebrew Bible. The beginning and end of a thing are idiomatically used to express the whole,

41 Plumptre, Ecclesiastes, 132.

42 Tur-Sinai, הספר, 147. This emendation has been previously suggested by Mitchel, and the critical edition of the Peshitta to Qohelet has 'amla. Cf. Mitchel, HG. “'Work' in Ecclesiastes.” JBL 32 (1913:12).

43 Graetz, Kohelet קהלת, 70.

44 Gordis, Koheleth - The Man and his world, 232.

45 Schmid, HH. Wesen und Geschichte der Weisheit. BZAW 101. Berlin: de Gruyter (1966:190).

46 Lichtheim, Ancient Egyptian Literature, 142. 
entirely, or all in all. It seems that Qohelet used the terms רוף and, rather than תחלה and אחרית (Qoh 10:13), to indicate clearly defined boundaries and complete understanding. Since from the theological perspective everything that happens is אלהים מעשה, it is not clear specifically what did Qohelet hope to know. Plumptre says: "In modern language he sees not 'the beginning and the end,' the whence and the whither, of his own being, or of that of the Cosmos." 47 This does not imply that the work of God is entirely, or altogether, incomprehensible to man. Perhaps, Qohelet had a more modest desire, understanding the heavenly wisdom exhibited in timeliness. Though such knowledge would still be incomplete, modern science shows that it could be very satisfying. In this context, God is neither compassionate nor capricious.

\section{Conclusion}

The preceding discussion, of a representative sample of exegetical efforts regarding the meaning of Qoh 3:11, shows that many have been swayed by the presence of בעתו in Qoh 3:11a and the temporal sense of העלם in Qoh 3:11b to look for links between Qoh 3:2-8 and Qoh 3:11. This is a meager and superficial basis for linking 3:11 with 3:2-8, which consequently produced strained and sometimes logically inconsistent interpretations. As has been implied in the discussion such a link is probably unwarranted. It seems likely that the limited list of events and their opposites were presented by the pragmatic Qohelet as an example for man to do things at the right time, according to accumulated experience and prevailing circumstances. The list is not a divinely preordained catalogue of seasons, nor is it related to העלם. There is substantially more textual and thematic evidence to view 3:11a as referring to the order and beauty of the creation, which is evident to our eyes.

The MT עירָ almost invariably signifies time past or present, unmeasured time, eternity, and in this sense it is used in the Book of Qohelet. At the same time, whenever God puts something into anyone's heart it is a thing which that person can do or know (Ex 31:6, 35:34, 36:2, Jer 32:40 [ראשית חכמה = יראה], Ps 4:8, 2 Chr 9:23). In most of the cases it is

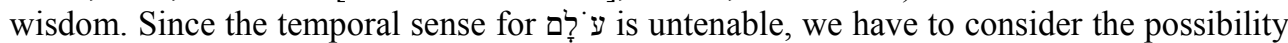
that the pointing of העלם has been affected by the temporal sense it has in the Hebrew Bible. Jewish sages felt that the defective form of העלם opens the door for other interpretations and this was exploited by Rashi (see ad loc). In modern exegesis, Barton and

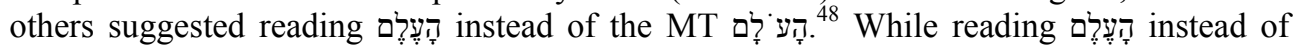
הע לָָם seems to us correct, and we offered substantial support for it in the discussion, the

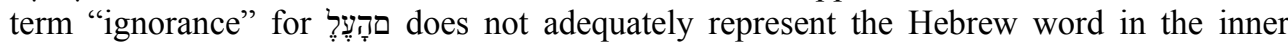
context of the verse. The limitations of the knowledge imparted to man naturally exposed

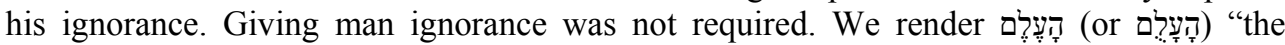
unknowable." Giving man a sense of the existence of the "unknowable" was not only needed but useful.

Ancient wisdom was not happy with statistical determinism. It desired absolute determinism, knowing the "single way," or as Qohelet puts it, "finding the work of God from beginning to end." If God follows a fixed plan nature should be accessible to man, and God's doings should not remain hidden from him. The חכם expected that wisdom would enable him to discern the order of the world by means of examined experience and accumulated knowledge and learn how to behave toward God, his fellowmen, and nature.

47 Plumptre, Ecclesiastes, 132. Plumptre believes that Qohelet suggests man is obsessed with what German thinkers have named the Welt-Schmerz.

48 Barton, Ecclesiastes, 98. 
The ultimate goal was "recognition of the right time, the right place and the right degree of human conduct." 49 Qohelet is not happy that this goal cannot be achieved in a strict deterministic sense because of the "unknowable" in their hearts (the seat of wisdom). Our reading "not to be happy," or in a later sense "not to be confirmed," instead of בל יאשר "מבלי מבלי reflects this unhappiness.

Qohelet's frustration is self-caused; it is not a fault of the system. For instance, modern science lives comfortable with the knowledge of its limitations. Heisenberg's uncertainty principle in atomic physics stipulates that the values of certain pairs of variables (e.g. position and momentum, or time and energy) cannot both be known with arbitrary precision. The more precisely we know one variable, the less precisely do we know the other variable in the pair. ${ }^{50}$ This uncertainty is a characteristic of nature. Every measuring device has a built in error, and any measurement disturbs the measured system. Repetition of measurements gives a distribution of values, which are only statistically meaningful. Even in mathematics, a creation of the human mind, there is fundamental uncertainty. Gödel's incompleteness theorems express the inherent limitations of all but the most trivial formal systems for arithmetic, which are of mathematical interest. They show that finding a complete and consistent set of axioms for all of mathematics is impossible. ${ }^{51}$

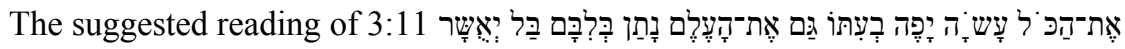

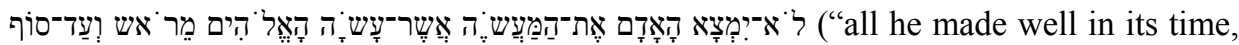
yet he placed the unknowable in their heart, not to make him happy, man cannot find out the work which God made from beginning to end"), which is based on minimal emendation of the MT, provides a good unforced sense that is in line with ancient wisdom thinking. Man can find out much about what God does (מעשה האלהים), but placing the "unknowable" in their heart does not allow an exact deterministic understanding of anything "from the beginning to end."

50 Heisenberg, W. "Über den anschaulichen Inhalt der quantentheoretischen Kinematik und Mechanik." Zeitschrift für Physik 43 (1927:172-198); Pinker, A. ספר האטום. Jerusalem: Ruben Mass (1964:226-230).

51 Gödel, K. "Some basic theorems on the foundations of mathematics and their implications" (1951). In Collected works/Kurt Gödel, Vol. III (ed. Feferman, S). Oxford: Oxford University Press (1995:304-23). 